\title{
THE PROFESSIONAL LEARNING COMMUNITY AS AN ORGANIZATIONAL SYSTEM FOR SCHOOL STAFF DEVELOPMENT, SCHOOL CHANGE AND IMPROVEMENT
}

\author{
Normunds Rečs \\ Tukums Municipality of Latvia, Latvia \\ Andrejs Geske \\ University of Latvia, Latvia
}

\begin{abstract}
In the context of the general education content reform initiated in Latvia, which also provides change of learning approach, involvement in mutual professional learning activities at school has raised the issue of teachers ' professional growth. In the scientific literature the concept of the professional learning communities (PLC) is considered to be an effective organizational system for school staff development, school change and improvement on the basis of two considerations. First of all it is presumed that teachers ' professional knowledge is a part of their everyday experience and that this knowledge is best understood in a critical exchange of ideas with other teachers, who have the same experience. Secondly it is assumed that teachers who are actively involved in the PLCs will be able to increase their professional knowledge and competence, thus contributing to students ' learning and their learning outcomes. The main goal of the research is to find out whether and to what extent teachers in the Latvian general education institutions take part in the PLCs. The article discusses theories of the concept of PLC and analyses the results of 489 teacher surveys. The results of empirical research do not show significant differences in the mean values of the PLC scales in primary and secondary schools. The data shows a very significant difference in the average values of the PLC scales in schools of the same level of education.

Keywords: general education, professional collaboration of teachers, professional learning communities, school leadership.
\end{abstract}

\section{Introduction}

Student learning outcomes depend to a large extent on the motivation and performance of each individual teacher in the classroom. Traditional teaching at school is practiced as the "solo art" of each individual teacher. The teaching autonomy of a teacher in many places is still considered to be 
untouchable, and the intervention is sharply at odds with existing practices (Pont et al., 2008). However the concept of the professional learning community (PLC) in school management and the studies over the last two decades give new perspectives on the professional development of teachers.

Teaching in the classroom is based on the practical knowledge of teachers (Van Driel et al., 2001). The practical knowledge of teachers is formed by working at their school, combining experimental knowledge, formal knowledge and personal beliefs. Consequently many teachers` beliefs and practical knowledge of teaching are limited to their personal experience by working at school (Namsone et al., 2016).

Traditional professional development models, on the other hand, aim to provide teachers with knowledge and skills needed to become "better" educators. These models are usually based on the presumption that the purpose of the professional development is to present teachers with "knowledge for practice", i.e., that the formal professional development activities are based on the assumption that knowledge and competence are best developed by university researchers outside the day-to-day pedagogical work and that by participating in formal processional development activity teachers acquire and apply this knowledge in their professional work in the classroom. In addition, the knowledge provided is generally recommended as a "recipe for better teaching" (Vescio et al., 2008).

In order to effectively improve the professional development of teachers, since the 90 `s of the XX century the emphasis of teacher professional development has gradually shifted from formal improvement of qualification in teacher professional development programmes to teacher cooperation in the PLCs, where teachers learn from each other within their schools (OECD, 2016). The researchers even suggest that the term "professional development" should be replaced with the term "professional learning" (Timperley et al., 2007; Easton, 2008; Stoll et al., 2012; Kools, \& Stoll, 2016; Schleicher, 2016). Professional learning between teachers enables them to share experience and deepen their knowledge of theoretical guidelines, methods and processes for teaching and learning, and to gain approval for their professional practices on the basis of the analysis of student achievements and other evidence of successful change. Despite these reasonable arguments, international research has shown that there still are a large proportion of teachers who have not participated in such professional development forms as mutual learning, joint teaching or involvement in joint professional development activities (OECD, 2014). This situation could be explained by the fact that teachers traditionally practice teaching as solo art individually and interference in the teaching autonomy of teachers is in contradiction with the existing practice (Pont et al., 2008). 
To change this situation, teachers should engage in a mutual exchange of experience at the PLCs in their school, analysing and reflecting realistic pedagogical challenges that would allow teachers to learn different kinds of experience, participate in discussions, exchange views, analyse and reflect on the teaching of their and their colleagues (Namsone et al., 2016). This is particularly relevant in the context of the general education content reform launched in Latvia, which also provides for a change in the teaching approach. The introduction of the new learning content and teaching approach needs to strengthen and develop cooperation between teachers at school level in the planning and implementation of the teaching and educational process, in order to harmonise content issues and improve curricula to regularly analyse student learning achievements and find the best solutions for raising the educational outcomes of each student, so that teachers can improve teaching and share good pedagogical practices with each other.

The main aim of the research is to find out whether and to what extent teachers in the Latvian general education institutions take part in the PLCs.

A theoretical analysis of the scientific literature was done within the research. Teacher survey made by the authors has been used as a measuring instrument for carrying out an empirical research. The study analysed the survey data of 489 teachers.

\section{Professional Learning Community}

Studies carried out in the recent decades have been based on an organisational approach to promoting the professional growth of teachers focusing on the development of the PLC at school (see, e.g., Louis et al., 1996; Hord, 1997; Bolam et al., 2005; Timperley et al., 2007; Vieluf et al., 2012; OECD, 2016; Schleicher, 2016).

According to the definition provided by the OECD researchers, the PLC is an inclusive and mutually supportive group of teachers with a collaborative, reflective and growth-oriented approach to study and learn more about their professional practice, with the main purpose to improve the learning of all students (Kools \& Stoll, 2016). The PLC is composed of joint purpose and task-driven professionals, who are constantly gaining new knowledge through interacting with each other and trying to improve their pedagogical practices (Hord, 1997; Louis et al., 1996).

The importance of the concept of the PLC in the context of school in the scientific literature is based on two considerations:

- first of all, it is presumed that the professional knowledge of teachers is part of their day-to-day experience and that this knowledge is best understood in a critical exchange of ideas with other teachers, who have the same experience; 
- secondly, it is assumed that teachers who are actively involved in the PLCs will be able to increase their professional knowledge and competence, thus contributing to students learning and their learning outcomes (Vescio et al., 2008; OECD, 2016). The empirical studies also show a positive link between the development of the PLCs in schools and their student achievements (Stoll et al., 2006; Lomos et al., 2011).

The concept of the PLC includes three important elements (Bolam et al., 2005; Stoll \& Louis, 2007; Hord \& Hirsch, 2008; Verbiest, 2011):

- the professionalism of teachers, based on their knowledge and shared responsibility;

- the mutual learning of teachers within the school, through critical evaluation and self-reflection, with the main purpose to improve their professionalism;

- the community as an indicator of the quality of the relationship between teachers, which makes mutual learning and growth possible.

The main focus of the concept of the PLC is the focus on the learning of each student; therefore, the involvement of teachers in the cooperation and their activities under the concept of the PLC is fundamentally different from the traditional approach of the activities of teachers, who are not active in the PLC at school (InPraxis Group Inc., 2006; Sigurdardóttir, 2010). These differences are described in Table 1.

Table 1. Differences between traditional approach and the approach of the PLC (InPraxis Group Inc., 2006)

\begin{tabular}{|c|c|}
\hline $\begin{array}{c}\text { In the traditional approach } \\
\text { teachers ... }\end{array}$ & $\begin{array}{l}\text { In the approach of } \\
\text { the PLCs, teachers ... }\end{array}$ \\
\hline - focus primarily on teaching & - focus primarily on each student`s learning \\
\hline $\begin{array}{l}\text { are isolated from one another, } \\
\text { the opportunities to cooperate } \\
\text { on strategies to improve student } \\
\text { learning are limited }\end{array}$ & $\begin{array}{l}\text { work in cooperation with other } \\
\text { teachers; feel collectively responsible } \\
\text { for the learning and growth of all school } \\
\text { teachers and students }\end{array}$ \\
\hline $\begin{array}{l}\text { - teach according to a set of } \\
\text { externally fixed curricular } \\
\text { standards that remain constant; } \\
\text { decide by themselves what to teach }\end{array}$ & $\begin{array}{l}\text { - see students` learning as an ongoing } \\
\text { process; jointly adjust the curriculum to } \\
\text { the learning needs of the students }\end{array}$ \\
\hline $\begin{array}{l}\text { - are given little or no time to work } \\
\text { in cooperation with colleagues }\end{array}$ & $\begin{array}{l}\text { - have structured time to observe and } \\
\text { reflect on each other work and serve as } \\
\text { critical friends in support of each other }\end{array}$ \\
\hline $\begin{array}{l}\text { - teach students according to their } \\
\text { individual understanding of } \\
\text { teaching styles and techniques }\end{array}$ & $\begin{array}{l}\text { build an understanding of each other's } \\
\text { style and technique so they can learn } \\
\text { from one another and complement each } \\
\text { other work }\end{array}$ \\
\hline
\end{tabular}


The concept of the PLC shifts from the traditional "teacher-oriented" approach to "student-centred" approach, where teachers work together and cooperate by focusing on a joint mission and building capacity, identify gaps in teaching and learning and develop effective pedagogical practices to ensure the needs of all students (Darling-Hammond, 1996).

Focus on professional learning communities in the school setting has resulted in a redefining of the teacher's role. The teacher is no longer a passive instructor, who simply transfers knowledge to the student, but an active agent of change, who leads the learning of a student (Cowan, 2003). When involving in the PLC teachers become empowered as they tackle initiatives and take risks, accept leadership responsibilities, and feel confident as professionals (Slater, 2008).

Researchers point out that teacher cooperation itself does not mean full functioning of the PLC. It is essential whether teacher cooperation in the PLC focuses on everyday work in the classroom with the main purpose to improve the learning of every student. The effectiveness of the PLC and the increase of the capacity of each teacher in the PLC depend on a large extent of collective self-analysis and feedback, the reduction of teacher isolation, the reflection of current teaching practices and shared responsibility for all students' learning. Thus, the student success is the only institutional priority of school as an organisation and its attention is shifted from the excuses and finding perpetrators to an approach focusing on the student individual needs (Du Four et al., 2006).

Studies (Hord, 1997; Vescio et al., 2008; Lomos et al., 2011) show positive effects of the PLC on both teachers and students. In the case of teachers, the PLC reduces teacher isolation; reinforces the commitment to the school mission and to the achievement of school objectives; increases collective responsibility for learning outcomes; stimulates deeper insight into their daily practices and critical analysis; activates mutual learning, builds better teaching practices and creates new knowledge and understanding of teaching and learning; reinforces awareness of students and their individual needs and the role of the teacher to help all students to achieve performancerelevant results; enables teachers to make a significant progress in adapting teaching to students' individual needs more quickly than traditional schools; ensuring teacher awareness; promoting professional renewal of teachers and the capacity to inspire and motivate students; promotes job satisfaction; stimulates commitment to make significant and lasting progress and change (Hord, 1997). The positive effects of the PLC teachers on students are evidenced by a decrease in the number of early school leavers and second-year students; a reduction in delays; higher school outcomes than in traditional schools; lower gaps in learning achievements among students at different capacity levels (Hord, 1997). 
In view of the complexity of the PLC, this study is based on the model developed by the Canadian scientists on the PLC as a multilevel multidimensional concept (Mitchell \& Sackney, 2011; Sleegers et al., 2013). That model reflects the PLC at three levels - the individual level of the PLC members, interpersonal level of the PLC members and the level of cooperation between the PLC members and school as an organisation. In each of these levels, a number of interrelated groups of characteristics or dimensions to describe the PLC are identified. The involvement in the PLC at individual level is characterised by active and reflective development of new professional knowledge of the member and the use of the good practice acquired by the participation in the PLC. The development of the PLC at interpersonal level is characterised by the dimensions of joint understanding of teachers on school mission, objectives, mutual cooperation between teachers, sharing professional knowledge and personal practices acquired at individual level, sharing responsibility for students' learning. Schools as the organizational level include the provision of such supportive resources necessary for the operation of the PLC as available time, information and materials, reflection of the support of school management for the professional cooperation of teachers, as well as the joint commitment of teachers to promote the success of each student in training.

In this research the authors focus on three interpersonal and two organizational levels that describe the formation of the organizational level PLC as variable scales, which content is described in Table 2.

\section{Methodology}

Teacher survey created by the authors of the research on the functioning of the PLC at school has been used as a measuring instrument for carrying out an empirical reserach.

The 40 statements were selected from surveys of British (Bolam et al., 2005) and Belgian (Vanblaere \& Devos, 2016) scientists based on the content of the PLC within this research.

The statements of the survey are grouped in five dimension scales of the PLC.

The Likert scale was used in the survey. The internal consistency of the survey variable scales has been verified by Cronbach alpha-factor. An overview of the number of teacher survey statements and Cronbach`s alpha-factor is given in Table 2 on each of the scales.

The teacher survey was conducted in school year 2017/2018 in 25 schools of the municipalities in the western part of Latvia. A total of 580 paper surveys were distributed, of which 489 or $84.3 \%$ were returned. Of the total, 306 teachers (63\% of respondents) were surveyed in 
11 secondary schools and 183 teachers (37\% of respondents) in 14 primary schools.

Table 2. The Scales of the PLC

\begin{tabular}{|c|c|c|c|}
\hline Scales & $\begin{array}{l}\text { Number } \\
\text { of items }\end{array}$ & $\begin{array}{c}\text { Cronbach } \\
\alpha\end{array}$ & Content of the dimensions of the PLC \\
\hline \multicolumn{4}{|l|}{ Interpersonal level } \\
\hline $\begin{array}{l}\text { Shared sense } \\
\text { of purpose and } \\
\text { values }\end{array}$ & 6 & .80 & $\begin{array}{l}\text { Reflects the degree of the agreement } \\
\text { between teachers on school mission, } \\
\text { common objectives and operational } \\
\text { principles }\end{array}$ \\
\hline $\begin{array}{l}\text { Collective focus } \\
\text { on students` } \\
\text { learning }\end{array}$ & 10 & .71 & $\begin{array}{l}\text { Describes a shared commitment of } \\
\text { teachers to improve student learning in } \\
\text { a long term }\end{array}$ \\
\hline $\begin{array}{l}\text { Sharing personal } \\
\text { practice }\end{array}$ & 7 & .70 & $\begin{array}{l}\text { Reflects discussions on teaching methods, } \\
\text { exchange of the ideas and problem- } \\
\text { solving advices between teachers based on } \\
\text { the classroom observations by colleagues }\end{array}$ \\
\hline \multicolumn{4}{|c|}{ Organizational level } \\
\hline $\begin{array}{l}\text { Collective } \\
\text { responsibility } \\
\text { for students' } \\
\text { learning }\end{array}$ & 10 & .83 & $\begin{array}{l}\text { Describes the commitment of teachers } \\
\text { to promote the intellectual growth and } \\
\text { development of each student and to } \\
\text { achieve the success of students in learning }\end{array}$ \\
\hline $\begin{array}{l}\text { Supporting } \\
\text { conditions }\end{array}$ & 7 & .68 & $\begin{array}{l}\text { Describes the support of } \\
\text { the administration to teacher professional } \\
\text { cooperation and growth }\end{array}$ \\
\hline
\end{tabular}

Of the total number of respondents, 445 (91\%) were women, while $44(9 \%)$ were men. The average age of the teachers involved in the study was 47.9 years (between 21 and 74 years). The gender profile of the sample respondents is in line with the conclusions of the OECD TALIS 2018 study on the gender ratio of Latvian teachers (89\% female and $11 \%$ male) (OECD, 2019). On average, the teachers involved in the study were slightly younger compared to the results of OECD TALIS 2018, which shows that $51 \%$ of Latvian teachers are older than 50 years (OECD, 2019).

The average duration of the total pedagogical length of service of the teachers involved in the study was 24.3 years (between 1 and 51 years).

The smallest number of teachers participating in the survey in one of the schools was eight teachers, and the largest was 44 teachers. An average number of teachers surveyed in one school - 19.6. On average, 23.5 teachers were surveyed in one secondary school and 15 teachers in primary schools.

All the schools involved in the research were general education primary or secondary schools funded by municipalities. The research did not 
involve gymnasiums, private schools, boarding schools, special schools or vocational orientation schools. In all schools in which the study was carried out, the training took place in Latvian.

\section{Results}

The survey data was processed using the SPSS program. The descriptive statistical methods (frequencies, weights) were used for the analysis of data to give an overall picture of the schools involved in the survey, the teachers surveyed and their answers.

The descriptive statistics compiled in Table 3 do not show any significant difference in the mean values of the PLC scales in primary and secondary schools. Only in the PLC scale "Sharing personal practice", secondary school teachers demonstrate more frequent involvement in the discussions of teaching methods and in exchange of the ideas and problem-solving advices among teachers than primary school teachers.

Table 3. Mean values and standard deviation ( $\delta$ ) of the PLC scales for primary and secondary schools

\begin{tabular}{|l|c|c|c|c|c|c|}
\hline \multirow{2}{*}{\multicolumn{1}{|c|}{ Scales* }} & \multicolumn{2}{|c|}{$\begin{array}{c}\text { Primary school teachers } \\
(\mathbf{N}=183)\end{array}$} & \multicolumn{2}{c|}{$\begin{array}{c}\text { Secondary school teachers } \\
\text { (N=306) }\end{array}$} \\
\cline { 2 - 8 } & \multicolumn{1}{|c|}{$(\boldsymbol{\delta})$} & $\boldsymbol{x}_{\min }$ & $\boldsymbol{x}_{\max }$ & $(\boldsymbol{\delta})$ & $\boldsymbol{x}_{\min }$ & $\boldsymbol{x}_{\max }$ \\
\hline $\begin{array}{l}\text { Shared sense of purpose } \\
\text { and values }\end{array}$ & $10.06(1.79)$ & 5.97 & 13.08 & $9.96(2.12)$ & 3.84 & 13.08 \\
\hline $\begin{array}{l}\text { Collective focus on } \\
\text { students' learning }\end{array}$ & $10.08(1.93)$ & 5.30 & 14.24 & $9.95(2.04)$ & 3.18 & 14.24 \\
\hline Sharing personal practice & $9.67(2.25)$ & 4.38 & 23.13 & $10.19(1.81)$ & 4.70 & 15.19 \\
\hline $\begin{array}{l}\text { Collective responsibility } \\
\text { for students' learning }\end{array}$ & $10.13(2.13)$ & 4.84 & 15.69 & $9.92(1.92)$ & 3.97 & 15.69 \\
\hline Supporting conditions & $10.04(1.72)$ & 4.53 & 14.80 & $9.97(2.15)$ & 3.96 & 16.51 \\
\hline
\end{tabular}

$N$ (teachers) $=489$ and $N$ (schools) $=25$

* Scales are recalibrated with an average of 10 and standard deviation 2

Table 4 summarises the mean values of the PLC scales for each school involved in the research. The data presented in Table 4 shows a very significant difference in the average values of the PLC scales in schools of the same level of education. For example, secondary schools "K" and "L" have significantly lower average values on several PLC scales. It is possible that the differences identified in the study between the PLC scales in schools of the same level of education can be explained by the fact that school principals do not have sufficient understanding of the importance of the PLC in promoting the professional development of teachers and that it 
is not self-evident for teachers to cooperate with each other in their schools and that it is not easy to break traditional views of teachers as firmly autonomous professionals.

Table 4. Mean values of the PLC scales in participating schools

\begin{tabular}{|c|c|c|c|c|c|c|}
\hline \multirow[b]{2}{*}{ 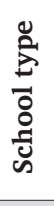 } & \multirow[b]{2}{*}{$\begin{array}{l}\overrightarrow{8} \\
\text { d } \\
\vec{j}\end{array}$} & \multicolumn{5}{|c|}{ Mean values* and standard deviation ( $\delta$ ) of the PLC scales } \\
\hline & & $\begin{array}{l}\text { Shared sense } \\
\text { of purpose } \\
\text { and values }\end{array}$ & $\begin{array}{l}\text { Collective } \\
\text { focus on } \\
\text { students } \\
\text { learning }\end{array}$ & $\begin{array}{l}\text { Sharing } \\
\text { personal } \\
\text { practice }\end{array}$ & \begin{tabular}{|l|} 
Collective re- \\
sponsibility \\
for students' \\
learning \\
\end{tabular} & $\begin{array}{l}\text { Supporting } \\
\text { conditions }\end{array}$ \\
\hline \multirow{13}{*}{ 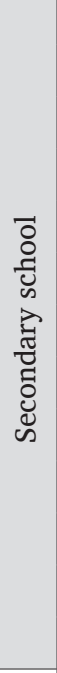 } & A & $9.59(2.10)$ & $9.99(2.14)$ & $10.79(1.80)$ & $10.23(2.25)$ & $10.67(1.60)$ \\
\hline & $\mathrm{B}$ & $9.76(1.75)$ & $9.82(1.83)$ & $10.33(1.30)$ & 9.87 (1.92) & $9.76(2.24)$ \\
\hline & $\mathrm{C}$ & 9.79 (1.89) & $9.61(2.23)$ & 10.78 (1.39) & $9.96(1.23)$ & $9.53(1.68)$ \\
\hline & $\mathrm{D}$ & $10.28(1.76)$ & $9.57(2.29)$ & $10.66(1.79)$ & $10.27(1.93)$ & 10.19 (1.77) \\
\hline & $\mathrm{E}$ & 11.68 (1.07) & $11.39(1.45)$ & $10.84(1.40)$ & $9.86(2.02)$ & 11.97 (1.30) \\
\hline & $\mathrm{F}$ & $11.12(1.85)$ & $10.50(2.21)$ & $9.36(1.68)$ & $9.45(2.07)$ & 10.76 (1.99) \\
\hline & G & $10.64(1.20)$ & 10.35 (1.48) & 9.29 (1.79) & $8.88(1.70)$ & $9.22(1.92)$ \\
\hline & $\mathrm{H}$ & $9.48(2.48)$ & $9.45(2.03)$ & $10.90(1.83)$ & $10.27(1.72)$ & 10.06 (1.95) \\
\hline & I & $11.17(1.24)$ & $10.33(1.84)$ & $10.40(1.66)$ & $10.35(1.94)$ & $10.39(1.80)$ \\
\hline & $\mathrm{J}$ & $9.67(2.05)$ & $9.89(2.25)$ & $9.40(1.56)$ & $9.77(1.28)$ & 9.87 (1.96) \\
\hline & $\mathrm{K}$ & $7.88(1.91)$ & $8.64(1.02)$ & $10.14(2.33)$ & $10.04(2.34)$ & $7.02(2.04)$ \\
\hline & $\mathrm{L}$ & $7.06(2.31)$ & $8.74(2.37)$ & $8.91(2.44)$ & 9.91 (1.87) & $7.81(2.27)$ \\
\hline & M & $9.52(2.63)$ & $10.05(2.06)$ & $9.16(1.64)$ & $10.32(1.89)$ & $10.08(2.04)$ \\
\hline \multirow{12}{*}{ 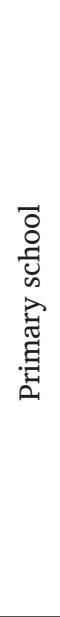 } & $\mathrm{N}$ & $10.47(1.90)$ & $10.21(1.94)$ & $9.61(1.92)$ & $10.12(2.10)$ & $10.31(1.79)$ \\
\hline & $\mathrm{O}$ & $10.11(1.85)$ & $10.26(1.83)$ & $9.99(2.02)$ & $9.72(2.18)$ & 9.99 (1.52) \\
\hline & $\mathrm{P}$ & $9.61(2.24)$ & $9.71(2.56)$ & $8.93(2.13)$ & $9.84(2.39)$ & $9.71(2.19)$ \\
\hline & $\mathrm{R}$ & $9.98(1.77)$ & 10.03 (1.98) & $10.22(1.81)$ & $10.28(2.04)$ & 9.33 (1.55) \\
\hline & $\mathrm{S}$ & $10.83(1.21)$ & $11.93(1.76)$ & $12.12(3.97)$ & $11.06(2.05)$ & $10.95(1.82)$ \\
\hline & $\mathrm{T}$ & $10.94(1.27)$ & $9.09(1.12)$ & $7.21(1.71)$ & $8.40(2.15)$ & $9.36(0.97)$ \\
\hline & $\mathrm{U}$ & $10.56(1.00)$ & $10.35(1.73)$ & $9.98(1.32)$ & $11.29(1.31)$ & $11.38(0.81)$ \\
\hline & $\mathrm{V}$ & $11.06(1.54)$ & 11.05 (1.66) & $9.65(1.84)$ & $11.28(1.27)$ & 10.33 (1.21) \\
\hline & $\mathrm{W}$ & $9.29(1.23)$ & 10.34 (1.58) & $10.21(2.59)$ & $10.59(2.31)$ & $9.54(1.82)$ \\
\hline & $\mathrm{X}$ & $8.69(1.78)$ & $9.16(2.07)$ & $8.49(1.89)$ & $9.20(2.39)$ & $9.19(1.91)$ \\
\hline & $\mathrm{Y}$ & $9.32(0.95)$ & $8.80(1.10)$ & $10.06(1.45)$ & $9.19(1.65)$ & $10.00(1.55)$ \\
\hline & $\mathrm{Z}$ & 9.15 (2.09) & $9.66(0.78)$ & $10.06(1.21)$ & $11.26(1.19)$ & $10.31(1.81)$ \\
\hline
\end{tabular}

$N$ (teachers) $=489$ and $N$ (schools) $=25$

* Scales are recalibrated with an average of 10 and standard deviation 2 


\section{Conclusions}

The results of an empirical research do not show significant differences in the mean values of the PLC scales in primary and secondary schools.

The very significant difference in the average values of the PLC scales in schools of the same level of education is explained based on two considerations. First of all, not all principals of the schools involved in the research understood the importance of teacher-mutual cooperation and learning for PLC. Secondly, it is not self-evident for teachers to cooperate in their school and to break the idea of teachers as firmly autonomous professionals in their classroom.

The results of the study are likely to reaffirm the conclusion that it is not easy for teachers to deviate from traditional professional autonomy and actively engage in professional cooperation and learning activities at their school, to hear and accept professional advice and constructive criticism from colleagues, thereby revolutionising their professional learning and skill habits. The regulatory framework in force in Latvia regarding the requirements for the professional development of teachers is also not aimed at promoting the involvement of teachers in professional cooperation and learning activities in their school and promoting the development of the PLC. Article 15 of the regulations of the Cabinet of Ministers of Latvia regarding the education and professional qualifications required for an educator and the procedures for the development of the professional competence of educators (2018) states that the educator of general, vocational and interest education shall develop his or her professional competence by studying the programme for the improvement of the professional competence of educators within a period of three years at the least amount of 36 hours. On the other hand, Article 19 of the same regulations states that in the development of the professional competence of an educator outside direct pedagogical tasks (participation in conferences, seminars, masterclasses, traineeship industry undertakings, participation in training organised by employers' organisations to promote the competitiveness of the educator, personal development) takes up topics within three years to a maximum of 12 hours. Consequently, it can be concluded that the requirements in force in Latvia for the professional development of teachers are mainly intended to implement the professional development of educators only in formal professional development programmes outside the day-to-day pedagogical work of the school, but within the meaning of the regulatory framework regarding the professional development of the teacher, the involvement of teachers in professional cooperation and learning activities in the school is not considered. 
It should be noted that in countries which education systems in the OECD PISA studies are characterised by high student learning outcomes, such as Singapore and Japan, the majority of teachers' professional development activities are carried out in their workplace -schools, where teachers and principals are jointly searching for optimal solutions for their schools to meet specific educational objectives and to solve pedagogical problems (Timperley et al., 2007; Vieluf et al., 2012; Kool \& Stoll, 2016; Scleicher, 2016).

It is therefore important that Latvian state education policymakers and educational quality monitoring institutions also officially recognize teacher professional development implemented by the PLC through the involvement of teachers in professional cooperation and learning activities at their school.

\section{References}

Bolam, R., McMahon, A., Stoll, L., Thomas, S., \& Wallace, M. (2005). Creating and Sustaining Effective Professional Learning Communities (Research Report RR637). Nottingham: National College for School Leadership.

Regulations of the Cabinet of Ministers of Latvia regarding the education and professional qualifications required for an educator and the procedures for the development of the professional competence of educators (2018). Ministru kabineta 2018. gada 11. septembra noteikumi Nr. 569 "Noteikumi par pedagogiem nepieciešamo izglìtïbu un profesionālo kvalifikāciju un pedagogu profesionālās kompetences pilnveides kārtību". Available at: https://likumi.lv/ta/id/301572-noteikumi-par-pedagogiem-nepieciesamoizglitibu-un-profesionalo-kvalifikaciju-un-pedagogu-profesionalas-kompetencespilnveides (in Latvian).

Cowan, D. F. (2003). The PLC connection to school improvement. In J. B. Huffman \& K. K. Hipp (Eds.). Reculturing schools as professional learning communities (pp. 75-82). Lanham, MD: Scarecrow Education.

Darling-Hammond, L. (1996). The quiet revolution: Rethinking teacher development. Educational Leadership, 53(6). 4-10.

Du Four, R., Eaker, R., \& Many, T. (2006). Learning by doing: A handbook for Professional Learning Communities at work. Solution Tree USA.

Easton, L. B. (2008). From professional development to professional learning. Phi Delta Kappan, 89(10). 755-759.

Hord, S. (1997): Professional learning communities: communities of continuous inquiry and improvement. Austin: Southwest Educational Development Laboratory.

Hord, S., \& Hirsh, S. (2008): Making the promise a reality. In A. Blankstein, P. Houston, \& R. Cole (Eds.) Sustaining professional learning communities (pp. 23-40). Thousand Oaks: Corwin Press.

InPraxis Group Inc. (2006). Professional Learning Communities: an exploration. Edmonton: Alberta Education.

Kools, M., \& Stoll L. (2016). What Makes a School a Learning Organisation? (OECD Education Working Papers, No. 137). Paris: OECD Publishing. 
Lomos, C., Hofman, R. H., \& Bosker, R. J. (2011). Professional communities and student achievement - a metaanalysis. School Effectiveness and School Improvement, 22(2). 121-148.

Louis, K. S., Marks, H., \& Kruse, S. (1996). Teachers' Professional Community in Restructuring Schools. American Journal of Education, 104(2). 103-147.

Mitchell, C., \& Sackney, L. (2011). Profound improvement: Building learning-community capacity on living-system principles. New York: Routledge.

Namsone, D., Čakāne, L., \& Sarceviča-Kalviške, D. (2016). Teacher teams and schools become leaders to disseminate innovative practice. In SOCIETY. INTEGRATION. EDUCATION. Proceedings of the International Scientific Conference. Volume II, May $27^{\text {th }}-28^{\text {th }}$, 2016., pp. 208-222.

OECD (2014). TALIS 2013 Results: An International Perspective on Teaching and Learning. Paris: OECD Publishing.

OECD (2016). School Leadership for Learning: Insights from TALIS 2013. Paris: OECD Publishing.

OECD (2019). TALIS 2018 Results. Teachers and School Leaders as Lifelong Learners. Volume I. Paris: OECD Publishing.

Pont, B., Nusche, D., \& Moorman, H. (2008). Improving school leadership, Volume 1: Policy and practice. Paris: OECD publishing.

Schleicher, A. (2016). Teaching Excellence through Professional Learning and Policy Reform: Lessons from Around the World. International Summit on the Teaching Profession. Paris: OECD Publishing.

Sigurdardóttir, A. K. (2010). Professional Learning Community in Relation to School Effectiveness. Scandinavian Journal of Educational Research, 54(5). 395-412.

Slater, L. (2008). Pathways to building capacity. Educational Management Administration \& Leadership, 36(1). 55-69.

Sleegers, P., den Brok, P., Verbiest, E., Moolenaar, N. M., \& Daly, A. J. (2013). Towards conceptual clarity: A multidimensional, multilevel model of professional learning communities in Dutch elementary schools. The Elementary School Journal, 114(1). 118-137.

Stoll, L., Bolam, R., McMahon, A., Thomas, S., Wallace, M., Greenwood, A., et al. (2006). Professional learning communities: Source materials for school leaders and other leaders of professional learning. London: DfES.

Stoll, L., Harris, A., \& Handscomb, G. (2012). Great professional development which leads to great pedagogy: nine claims from research. Nottingham: National College for School Leadership.

Stoll, L., \& Louis, S. K. (2007). Professional Learning Communities: Divergence, Depth and Dilemmas. Maidenhead, Berkshire: Open University Press.

Timperley, H., Wilson, A., Barrar, H., \& Fung, I. (2007). Teacher Professional Learning and Development. Best Evidence Syntheses Iteration. Wellington: New Zealand Ministry of Education.

Vanblaere, B., \& Devos, G. (2016). Relating school leadership to perceived professional learning community characteristics: A multilevel analysis. Teaching and Teacher Education, 57. 26-38. 
Van Driel, J., Beijaard, D., \& Verloop, N. (2001). Professional development and reform in science education: the role of teachers' practical knowledge. Journal of Research in Science teaching, 38(2). 137-158.

Verbiest, E. (2011). Developing professional learning communities. Paper presented at the AERA conference, 2011, April $7^{\text {th }}-12^{\text {th }}$, New Orleans.

Vescio, V., Ross, D., \& Adams, A. (2008). A review of research on the impact of professional learning communities on teaching practice and student learning. Teaching and Teacher Education, 24. 80-91.

Vieluf, S., Kaplan, D., Klieme, E., \& Bayer, S. (2012). Teaching Practices and Pedagogical Innovation: Evidence from TALIS. Paris: OECD Publishing. 